\title{
Effects of plant density and proportion on the interaction between wheat with alexandergrass plants
}

\author{
Leonardo Bianco de Carvalho (1*); Pedro Luis da Costa Aguiar Alves ('); José Valcir Fidelis Martins ( ${ }^{1}$ ) \\ (') Faculdade de Ciências Agrárias e Veterinárias - UNESP/Câmpus de Jaboticabal, Departamento de Biologia Aplicada à \\ Agropecuária, Rod. Paulo Donato Castellane, s/n, 14884-900 Jaboticabal (SP). E-mail: agrolbcarvalho@gmail.com \\ (*) Autor correspondente.
}

Recebido: 28/Sept./2009; Aceito: 6/June/2010

\begin{abstract}
Determination of competitive relationships among plant species requires appropriate experimental designs and method of analysis. The hypothesis of this research was that two species growing in coexistence show different growth and development due to their relative competitiveness. This research aims to measure the relative competitiveness of wheat crop compared to Alexandergrass by the interpretation of plant density and proportional effects using replacement series experiments. Monocultures were cultivated in densities of 1, 3, 5, 10 and 15 plants per pot and analyzed by regression of dry mass data. Mixture experiment was cultivated in wheat:Alexandergrass proportions of 0:6, 1:5, 2:4, 3:3, 4:2, 5:1 and 6:0 plants per pot and analyzed by graphical interpretation of growth and production characteristics. Both experiments were carried out in randomized complete block design with four replicates. Alexandergrass was more sensitive to intraspecific competition than wheat. Alexandergrass was lightly more competitive than wheat. Number and weight of spikes and number of tillers were the wheat characteristics more affected by Alexandergrass interference.
\end{abstract}

Key words: Competition, Brachiaria plantaginea, Triticum aestivum, replacement series experiment.

\section{Efeitos da densidade e proporção de plantas na interação entre plantas de trigo e capim-marmelada}

\section{Resumo}

A determinação das relações competitivas entre espécies de plantas requer delineamentos experimentais e métodos de análise apropriados. A hipótese da pesquisa foi que duas espécies crescendo em convivência têm comportamento de crescimento e desenvolvimento distintos em função da sua competitividade relativa. O objetivo desta pesquisa foi quantificar a competitividade relativa da cultura do trigo com o capim-marmelada através da medida dos efeitos da densidade e da proporção de plantas, usando experimentos em série substitutiva. Monoculturas foram cultivadas em densidades de 1, 3, 5, 10 e 15 plantas por caixa e analisadas por regressão dos dados de massa seca, em 2006. Experimento em mistura foi cultivado nas proporções trigo:capim-marmelada de 0:6, 1:5, 2:4, 3:3, 4:2, 5:1 e 6:0 plantas por caixa e analisado através de interpretação gráfica de características de crescimento e produção, em 2007. Ambos os experimentos foram realizados em delineamento completamente casualizado com quatro repetições. Capim-marmelada foi mais sensível que trigo à competição intraespecífica. Capim-marmelada foi levemente mais competitivo que trigo. Número e massa de espigas e número de afilhos foram as características do trigo mais afetadas pela interferência do capim-marmelada.

Palavras-chave: Competição, Brachiaria plantaginea, Triticum aestivum, experimento substitutivo. 


\section{INTRODUCTION}

Determination of competitive relationships between plant species requires appropriate experimental designs and method of analysis (Roush et al., 1989; Cousens, 1991). These competitive relationships are influenced for several factors. Pitelli (1985) reports a diagram model with these factors, through adaptation of Bleasdale's model. Thus, with respect to factors linked to weeds, plant density is one of the most important, so that the higher density, the higher number of individuals competing for the same environmental resources, and then the competition with crops will be more intense (Christoffoleti and VictoRIA FiLHO, 1996).

In agriculture areas, crop density is kept constant whereas weed density varies in accordance to local infestation degree. Therefore, variation in plant proportion of crops and weeds is established. Thus, in competition studies, it is important to measure the influence of plant density on competitive process as well as the variation in plant proportion (Christoffoleti and Victoria Filho, 1996).

There are several methodologies used to study plant competition (RAdosevich, 1987; Roush et al., 1989; Cousens, 1991). However, most researchers measured just the interference of weeds on crop growth and production without concerning on the competition process. Thus, it is important to use appropriate experimental designs and method of analysis with a view to understand the competition process not just quantifying crop losses but in a mechanistic way (Christoffoleti and VictoRIA FILHo, 1996). Among methodologies already used, replacement series experiments are an alternative way to understand the plant competition process in especial the relation to plant density and proportion. This method allows clearing up competitive relationship among different plant species (Roush et al., 1989).

Replacement series experiments allow the control of plant density and proportion, where plant density is kept constant while plant proportion is changed for both studied species (WIt, 1960; Harper, 1977). In these experiments, it is admitted that the total plant density is sufficient to satisfy the "final constant production", where the biomass production per area is independent of plant density (Christoffoleti and Westra, 1994; ChristofFOLETI and Victoria FilHo, 1996).

Data interpretation of replacement series experiments results in a measurement of species competitiveness based on relative response to biomass production in function of plant proportion variation (Wit and Van Den Bergh, 1965; Mcgilchrist and Trenbath, 1974; Harper, 1977). Thus, it is possible to establish the competitive relationship between species by graphical visualization (Spitters, 1983; Jolliffe et al., 1984; Radosevich et al., 1997). This methodology has been successfully used to study crop-weeds interaction by Estorninos Jr. et al. (2002), Hoffman and Buhler (2002), VILÁ et al. (2004), Bianchi et al. (2006), Agostinetto et al. (2008), FleCK et al. (2008) and Rigoli et al. (2008). The confidence degree of this method of data interpretation is equivalent to competition coefficient estimative (RADOSEVICH et al., 1997), so that it can be used securely instead of any other method.

Although Brachiaria plantaginea (Link) Hitch (Alexandergrass) is not the most important weed in Triticum aestivum L. (wheat crop), this species is frequently found in areas cropped with this cereal in the South of Brazil. Rodrigues et al. (2000) reported that, although the Alexandergrass emergence is more frequent in summer season, it can also emerge substantially in winter season and then infest winter crops. Moreover, this species is resistant to ACCase inhibitor herbicides commonly used in soybean in a rotation with wheat (CHristoffoleti et al., 2001). Thus, this weed can increase its population if the control is not well done, and then compete with wheat for environmental resources needed to plant growth and development.

Considering the importance of Alexandergrass in wheat crop and because both species are monocots, the use of herbicides for Alexandergrass control becomes a challenge in wheat crop management. So, knowledge of Alexandergrass and wheat competitive relationship may be used to help establish management strategies for controlling this weed. The research hypothesis was that two species growing in coexistence have different growth and development behavior due to their relative competitiveness. Thus, the objective of this research was to measure the relative competitiveness of wheat crop with Alexandergrass by the interpretation of plant density and proportional effects using replacement series experiments.

\section{MATERIAL AND METHODS}

The experiments were carried out in July and September 2006 (monocultures) and July and October 2007 (replacement series). Formerly, two experiments were conducted with wheat and Alexandergrass monocultures. Pots $(63 \times 63 \times 30 \mathrm{~cm})$ were filled with substrate composed by soil and manure in a proportion $3: 1$. It was kept the numbers of 1,3, 5, 10 and 15 plants per pot. Wheat and Alexandergrass were randomly planted in the pots. The experiments were conducted in randomized complete block design with four replicates.

The replacement series experiment was conducted subsequently to monoculture experiments. It was also conducted in pots $(63 \times 63 \times 30 \mathrm{~cm})$ filled with substrate composed by soil and manure in a proportion $3: 1$. It was established different plant proportions keeping final plant density constant. Proportions between wheat: Alexandergrass plants were $0: 6,1: 5,2: 4,3: 3,4: 2,5: 1$ and 6:0. 
Wheat and Alexandergrass were also randomly planted in the pots. The experiments were conducted in randomized complete block design with four replicates.

It was not necessary to apply either fungicides or pesticides as long as water was supplied sufficiently to a good development of weed and crop, in both experiments.

In monoculture experiments, shoot of both species were collected on September 6th (50 days after planting). Shoot dry mass was weighted (analytical balance) after drying at $70^{\circ} \mathrm{C}$ in a forced air convection oven during 96 hours. Data were submitted to regression analysis by Boltzmann sigmoid model:

$$
y=\frac{A 1-A 2}{1+\exp ^{(x-x 0) / d x}}+A 2
$$

Boltzmann equation where: $y$ indicates dry mass accumulation; $A 1-A 2$ indicates production loss; $x$ indicates plant density; $x_{0}$ indicates plant density achieving $50 \%$ of "final constant production"; and $d x$ indicates tangent in $x_{0}$.

Dry mass data were also plotted in a graphic and compared to the standard error. Data interpretation was in accordance with the previously cited "final constant production" (Christoffoleti and Westra, 1994; Christoffoleti and Victoria Filho, 1996).

In replacement series experiment, results were evaluated in two dates. Leaf area (Li-Cor 3000A equipment), number of tillers and dry mass accumulation for both species, in addition to wheat plant height and number of spikes, were measured on August 30 (50 days after planting). Wheat and Alexandergrass leaf area, number of tillers and dry mass accumulation data were analyzed visually by interpretation of the graphic of relative production response in function of plant proportion (WIT, 1960; WIT and Van Den Bergh, 1965; Harper, 1977; Spitters, 1983; Jolliffe et al., 1984). In addition, it was analyzed the behavior of wheat plant height and number of spikes in relation to Alexandergrass dry mass accumulation. Furthermore, on October 9th (90 days after planting), the behavior of plant height, length, weight and number of spikes, and number of tillers of wheat crop were also analyzed in function of Alexandergrass dry mass accumulation. Ninety days after planting, higher agronomic interesting wheat characteristics more affected by the coexistence with Alexandergrass were also submitted to regression analysis.

\section{RESULTS AND DISCUSSION}

Wheat and Alexandergrass monocultures achieved the "final constant production" of dry mass accumulation before 15 plants per pot, according to Boltzmann regression curve (Figure 1). Plant density achieving 50\% of "final constant production" may be used to compare plant sensitivity to intraspecific competition, so that lower values indicate more sensitive species (CHRISTOFfoleti and Westra, 1994; Christoffoleti and VictoRIA FILHo, 1996). Thus, comparing the parameter $x_{0}$ of Boltzmann equation, Alexandergrass showed $\mathrm{x}_{0}$ equal to 1.57 while wheat showed 2.10 , indicating that the weed was more sensitive to intraspecific competition than the crop.

Despite the stabilization of wheat and Alexandergrass theoretical dry mass accumulation occurred after 11 and 8 plants, respectively, wheat dry mass was equal after density of 5 plants per pot while Alexandergrass dry mass was equal after 3 plants per pot, comparing the standard errors (Figure 1). Thus, we may consider that the final constant dry mass production was established over these densities. Increasing plant density, the intraspecific competition is established thereby environmental resources are limited to plants, reducing their development (RADOSEvich et al., 1997). Due to this fact, as plant density increases, the individual plant weight gets lower.

According to Jolliffe et al. (1984), the highest density achieved in monocultures experiments have to be used as the maximum number of plants in replacement series experiments. Thus, plant density in replacement
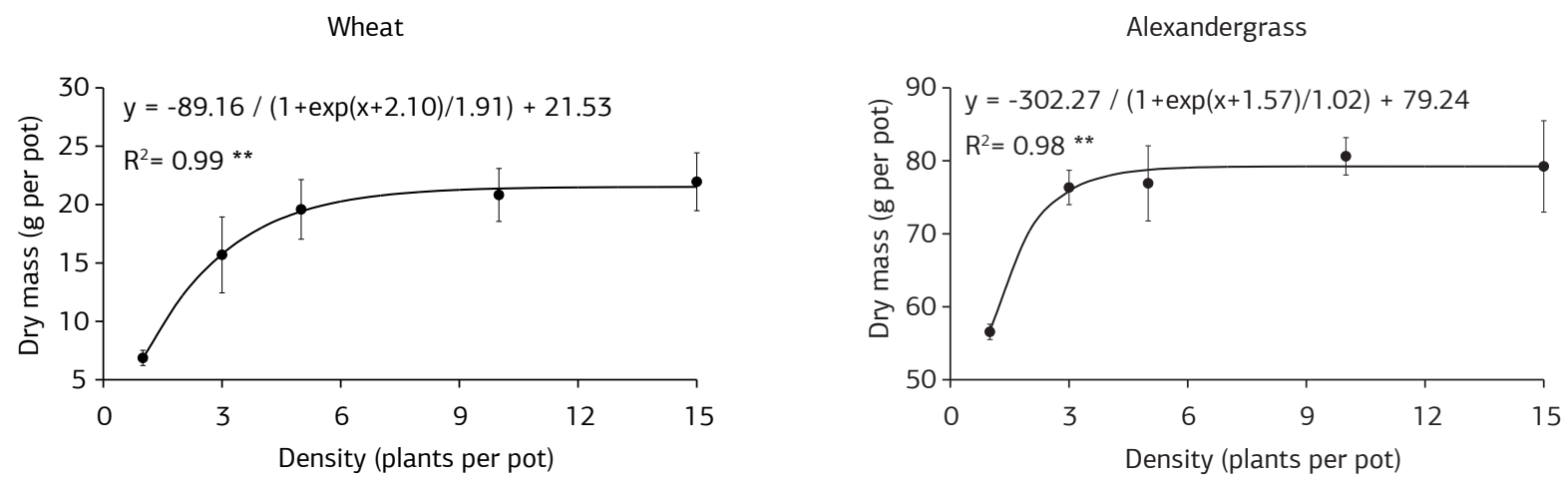

Figure 1. Behavior of dry mass accumulation of wheat and Alexandergrass monocultures in response to plant density. The symbol shows the average value of four replicates. 
series experiment should be 5 plants per pot. However, we opted for 6 plants per pot because wheat regression curve showed better stabilization just over this density.

Wheat and Alexandergrass mixture showed different response in function of that it was studied 50 days after planting. Relative leaf area was increased in both species once kept in mixture (Figure 2a). However, relative number of tillers and dry mass accumulation were slightly increased in Alexandergrass and slightly decreased in wheat once kept in mixture (Figure 2b, 2c). According to interpretation of Radosevich et al. (1997), it is evident that both species showed higher leaf area once in mixture, indicating mutual benefices. Alexandergrass was also beneficial in mixture cultivation while wheat was denigrated, considering both number of tillers and dry mass accumulation; furthermore, we may observe that there was a slight increase of the sum parameter,

(a)

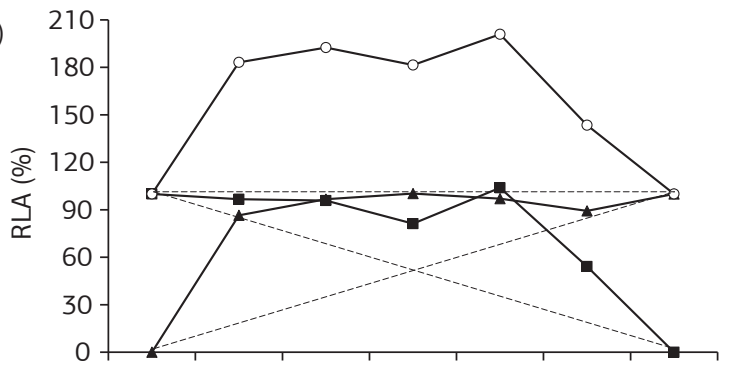

(b)
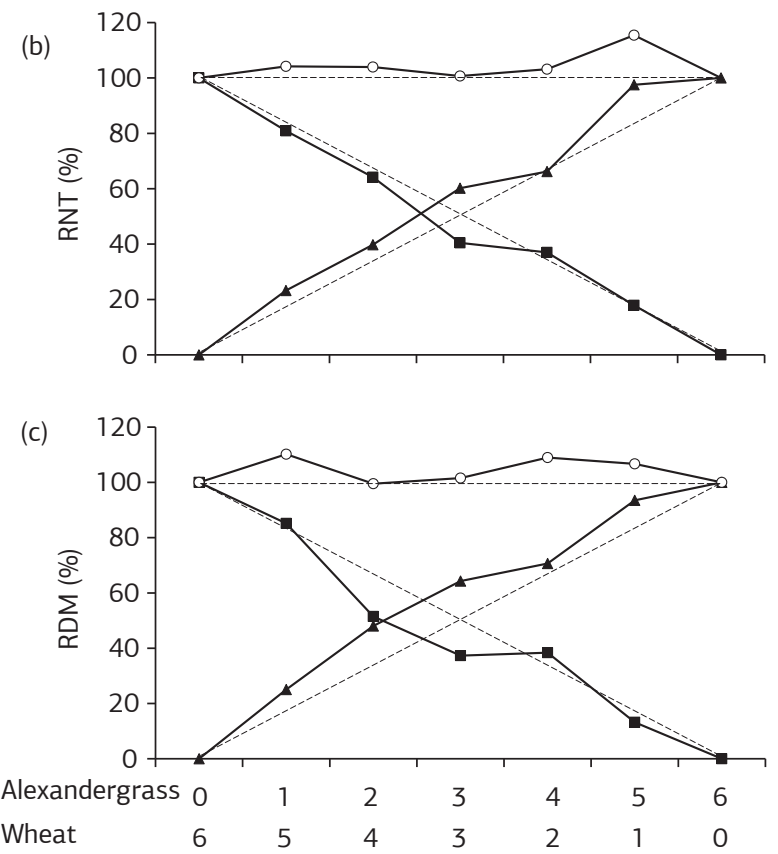

Density (plants per pot)

- Wheat $\star$ Alexandergrass -0 -Sum

Figure 2. Relative leaf area - RLA (a). Relative number of tillers - RNT (b). Relative dry mass accumulation - RDM (c) of wheat and Alexandergrass in response to plant proportion. Each symbol shows the average value of four replicates. The traced line indicates the equivalent production. indicating that Alexandergrass made more efficiently use of environmental resources than wheat in spite of competing for these same resources, according to interpretation of RADOSEVICH et al. (1997). Moreover, still 50 days after planting, as Alexandergrass dry mass accumulation was increased, wheat number of spikes gets lower, mainly after proportion 1:5; but wheat plant height was strongly reduced just after proportion 4:2 (Figure 3a). It shows that wheat number of spikes was more sensitive to Alexandergrass interference than plant height.

Now, 90 days after planting, as Alexandergrass dry mass accumulation was increased, wheat number and weight of spikes and number of tillers got lower; but wheat plant height and length of spikes were strongly reduced just after proportion 4:2 (Figure 3b). It shows that wheat number and weight of spikes and number of tillers were more sensitive to Alexandergrass interference than plant height and length of spikes. So we might confirm that higher agronomic interesting characteristics as number and weight of spikes were strongly reduced, so that at $50 \%$ of wheat population the decreasing was over $65 \%$ and $63 \%$, respectively, according to the regression equations (Figure $4 \mathrm{a}, \mathrm{b}$ ).
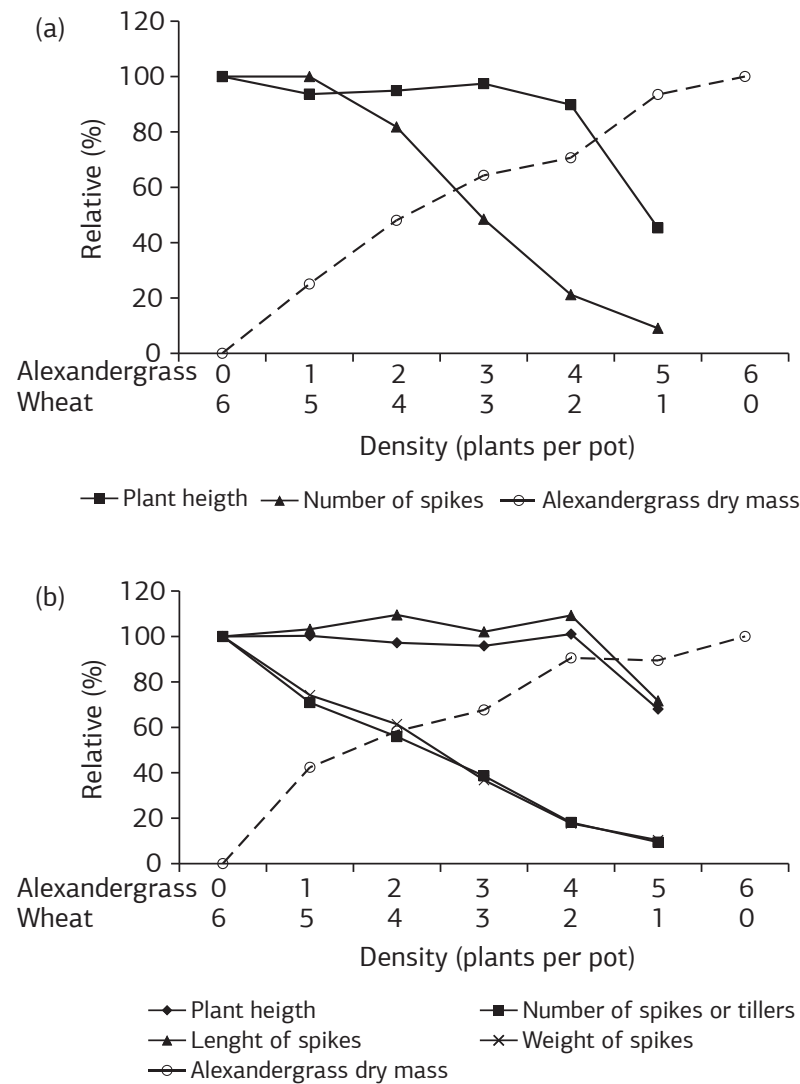

Figure 3. Relation of plant height and number of spikes of wheat with Alexandergrass dry mass at 50 days after planting (a) and of plant height, number and length and weight of spikes, and number of wheat with Alexandergrass dry mass at 90 days after planting (b). Each symbol shows the average value of four replicates. 

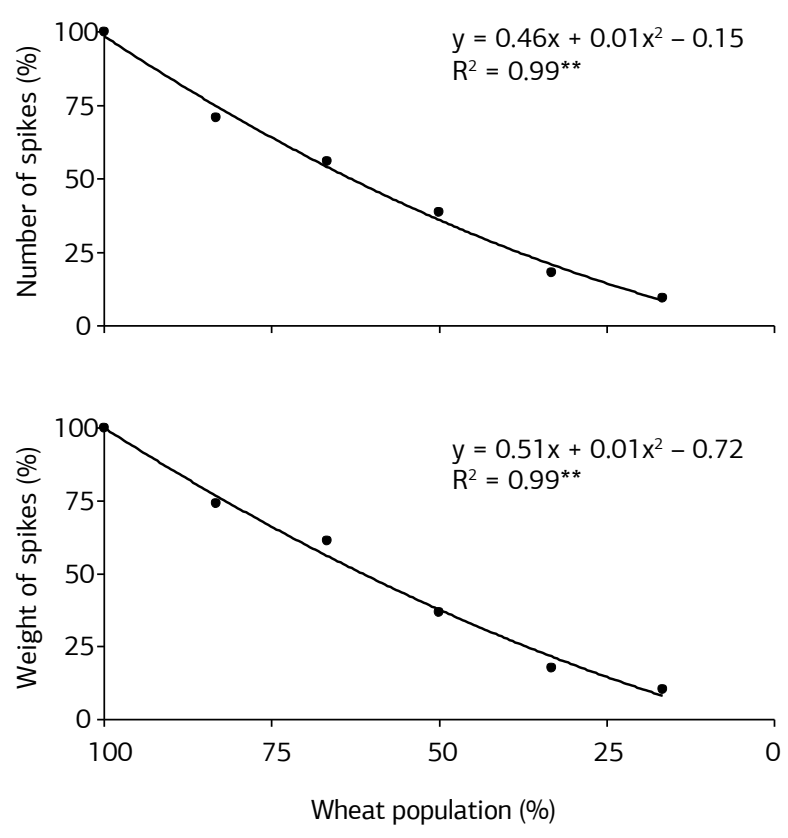

Figure 4. Behavior of the number of spikes and the weight of spikes of wheat growing in coexistence with Alexandergrass in function of the crop population decrease, at 90 days after planting. Each symbol shows the average value of four replicates.

The fact of lower number of tillers had been observed when weeds coexisted with wheat crop might be explained by the highest resources allocation in principal stem caused by low quality of light reflected to crop, reducing tiller allocation (Almeida and Mundstock, 2001). As a consequence, number, length and weight of spikes were also reduced; once these production characteristics are determined by wheat tillering (Alves et al., 2005). The most important consequences of light quality cues, often mediated by decreasing in red far-red ratios with respect to the spectral composition of incident sunlight radiation affecting weed-crop interaction are changes in plant morphology in anticipation of competition by light quantity, water or nutrients (Mеrotto Jr. et al., 2009). Thus, as a final consequence of competition for limited environmental resources, Alexandergrass will cause reduction on wheat crop yield.

\section{CONCLUSION}

Alexandergrass is more sensitive to intraspecific competition than wheat and lightly more competitive than wheat. Number and weight of spikes and number of tillers are the wheat characteristics more affected by Alexandergrass interference.

\section{REFERENCES}

AGOSTINETTO, D. GALON, L.; MORAES, P.V.D.; RIGOLI, R.P.; TIRONI, S.P.; PANOZZO, L.E. Competitividade relativa entre cultivares de arroz irrigado e biótipo de capim-Arroz (Echinochloa spp.). Planta Daninha, v.26, p.757-766, 2008.

ALMEIDA, M.L.; MUNDSTOCK, C.M. A qualidade da luz afeta o afilhamento em plantas de trigo, quando cultivadas sob competição. Ciência Rural, v.31, p.401-408, 2001.

ALVES, A.C.; MUNDSTOCK, C.M.; MEDEIROS, J.D. Iniciação e emergência de afilhos em cereais de estação fria. Ciência Rural, v.35, p.39-45, 2005.

BIANCHI, M.A.; FLECK, N.G.; LAMEGO, F.P. Proporção entre plantas de soja e plantas competidoras e as relaçóes de interferência mútua. Ciência Rural, v.36, p. 1380-1387, 2006.

CHRISTOFFOLETI, P.J.; WESTRA, P. Competition effects with mixed stands of wheat and kochia (Kochia scoparia) biotypes resistant and susceptible to acetolactase synthase inhibitor herbicides. Scientia Agricola, v.51, p.245-251, 1994.

CHRISTOFFOLETI, P.J.; VICTORIA FILHO, R. Efeitos da densidade e proporção de plantas de milho (Zea mays L.) e caruru (Amaranthus retroflexus L.) em competição. Planta Daninha, v.14, p.42-47, 1996.

CHRISTOFFOLETI, P.J.; KEHDI, C.A.; CORTEZ, M.G. Manejo da planta daninha Brachiaria plantaginea resistente aos herbicidas inibidores da ACCase. Planta Daninha, v.19, p.61-66, 2001.

COUSENS, R. Aspects of the design and interpretation of competition (interference) experiments. Weed Technology, v.5, p.664-673, 1991.

ESTORNINOS JR., L.E.; GEALY, D.R.; TALBET, R.E. Growth response of rice (Oryza sativa) and red rice (O. sativa) in replacement series study. Weed Technology, v.16, p.401-406, 2002.

FLECK, N.G. AGOSTINETTO, D.; GALON, L.; SCHAEDLER, C.E. Competitividade relativa entre cultivares de arroz irrigado e biótipo de arroz-vermelho. Planta Daninha, v.26, p.101-111, 2008.

HARPER, J.L. Mixtures of species. I. Space and proportions. In: HARPER, J.L. The population biology of plants. Academic Press: London, 1977. p.237-304.

HOFFMAN, M.L.; BUHLER, D.D. Utilizing Sorghum as a functional model of crop-weed competition. I. Establishing a competitive hierarchy. Weed Science, v.50, p.466-472, 2002.

JOLLIFFE, P.A.; NINJAS, A.N.; RUNECKLES, V.C. A reinterpretation of yield relationships in replacement series experiments. Journal of Applied Ecology, v.21, p.227-243, 1984.

MCGILCHRIST, C.A.; TRENBATH, B.R. A revised analysis of plant competition experiments. Biometrics, v.27, p.659-671, 1974.

MEROTTO JR., A.; FISCHER, A.J.; VIDAL, R.A. Perspectives for using light quality knowledge as an advanced ecophysiological weed management tool. Planta Daninha, v.27, p.407-419, 2009.

PITELLI, R.A. Interferência de plantas daninhas em culturas agrícolas. Informe Agropecuário, v.11, p.16-27, 1985. 
RADOSEVICH, S.R. Methods to study interactions among crops and weeds. Weed Technology, v.1, p.190-198, 1987.

RADOSEVICH, S.; HOLT, J.; GHERSA, C. Weed ecology: implications for management. 2.ed. New York: Wiley, 1997. $588 \mathrm{p}$.

RIGOLI, R. P. AGOSTINETTO, D.; SCHAEDLER, C.E.; DAL MAGRO, T.; TIRONI, S. Habilidade competitiva relativa do trigo (Triticum aestivum) em convivência com azevém (Lolium multiflorum) ou nabo (Raphanus raphanistrum). Planta Daninha, v.26, p.93-100, 2008.

RODRIGUES, B.N.; VOLL, E.; YADA, I.F.U.; LIMA, J. Emergência do capim-marmelada em duas regiōes do Estado do Paraná. Pesquisa Agropecuária Brasileira, v.35, p.2363-2373, 2000.
ROUSH, M.L.; RADOSEVICH, S.; WAGNER, R.G.; MAXWELL, B.; PETERSON, T.D. A comparison of methods for measuring effects of density and proportion in plant competition experiments. Weed Science, v.37, p.268-275, 1989.

SPITTERS, C.J.T . An alternative approach to analysis of mixed cropping experiments. I. Estimation of competition effects. Netherlands Journal of Agricultural Science, v.31, p.1-11, 1983.

VILÁ, M.; WILLIAMSON, M.; LONSDALE, M. Competition experiments on alien weeds with crops: lessons for measuring plant invasion impact? Biological Invasions, v.6, p.59-69, 2004.

WIT, C.T. On competition. Verslagen Landbouwk Onderzoek, v.66, p.1-82, 1960.

WIT, C.T.; VAN DEN BERGH, J.P. Competition between herbage plants. Netherlands Journal of Agricultural Science, v.13, p.212-221, 1965 . 